\title{
Efektivitas Penggunaan Booklet Terhadap Tingkat Kepatuhan Minum Obat Pasien DM Tipe 2 Di Puskesmas Wua-Wua Kota Kendari Tahun 2018
}

\section{(Effectiveness Booklet Usage on Compliance Level Of Taking Medication Of Patients With DM Type 2 In Wua-Wua Health Care Center Kendari City 2018)}

\author{
Sabarudin ${ }^{1 *}$, Henny Kasmawati ${ }^{1}$, Rini Hamsidi ${ }^{2}$, LM Fitrawan ${ }^{1}$, Rani Vitria ${ }^{1}$, Andi Nafisah Tendri \\ Adjeng1 \\ ${ }^{1}$ Fakultas Farmasi Universitas Halu Oleo, Kampus Hijau Bumi Tridharma Anduonohu, Jl. H. E. A. \\ Mokodompit Kendari 93232 \\ ${ }^{2}$ Fakultas Vokasi Universitas Airlangga, Kampus B UNAIR Jl. Dharmawangsa Dalam No. 28-30, Surabaya \\ 60286
}

Email : andres_sabar@yahoo.com

\author{
Article Info: \\ Received: 20 March \\ 2020 \\ Accepted: 6 April 2020 \\ DOI: \\ 10.33772/pharmauho. \\ v6i2.11501
}

\section{Abstract}

Diabetes mellitus (DM) is chronic metabolic disease characterized by increased blood glucose levels. Low medication compliance for treatment therapy in patients with type 2 diabetes can result in increased risk of treatment costs and increased disease complications. One way to improve adherence of treatment can be done by providing education. Education can be done in various ways one of them is by giving booklet. This study aims to determine the level of compliance for taking medication of patients with type $2 \mathrm{DM}$ before and after the administration of the booklet seen from the level of Blood Glucose While (GDS) and Morisky Medication Adherence Scale-8 (MMAS-8) scores and determine the relationship between GDS levels and MMAS-scores 8 to the level of compliance for taking medication of patients with type $2 \mathrm{DM}$ in Wua-Wua Health Center, Kendari City in 2018. This research is quasi-experimental study type with 40 patients with type 2 DM divided into 2 groups: 20 control group and 20 intervention group. Blood glucose levels and MMAS8 scores were measured before and after four weeks of intervention. The results showed that there were differences in the level of compliance for taking medication of type 2 DM patients at Wua-Wua Health Center in Kendari City before and after the booklet was given. Based on the level of GDS, the control group before and after the administration of the booklet was $296.2 \mathrm{mg} / \mathrm{dL}$ down to $261.85 \mathrm{mg} / \mathrm{dL}$, while the intervention group that was $275.7 \mathrm{mg} / \mathrm{dL}$ fell to $198.1 \mathrm{mg} / \mathrm{dL}$. Based on MMAS-8 scores in the control group before and after the administration of the booklet, it was 3.4 to 2.35 while the intervention group was 4.45 to 0.8 . The Spearman correlation test results showed that there was strong relationship $(\mathrm{r}=0.783)$ between the blood glucose levels when with MMAS-8 scores in type 2 DM patients in describing the level of compliance of patients with level $p=0,000(p<0.05)$, $p$ value indicates that DM education through effective booklet administration trust helps improve patient compliance which can be seen from low MMAS8 scores and low GDS levels.

Keywords: DM Type 2, MMAS-8, Booklet, Compliance 
2018. Jenis penelitian ini adalah penelitian quasi eksperimental dengan sampel sebanyak 40 pasien DM tipe 2 yang dibagi menjadi 2 kelompok yaitu 20 pasien kelompok kontrol dan 20 pasien kelompok intervensi. Kadar glukosa darah sewaktu dan skor MMAS-8 diukur sebelum dan setelah empat minggu pemberian intervensi. Hasil penelitian menunjukkan bahwa terdapat perbedaan tingkat kepatuhan minum obat pasien DM tipe 2 di Puskesmas Wua-Wua Kota Kendari sebelum dan setelah pemberian booklet. Berdasarkan kadar GDS, kelompok kontrol sebelum dan setelah pemberian booklet yaitu $296,2 \mathrm{mg} / \mathrm{dL}$ turun menjadi $261,85 \mathrm{mg} / \mathrm{dL}$, sedangkan kelompok intervensi yaitu $275,7 \mathrm{mg} / \mathrm{dL}$ turun menjadi 198,1 mg/dL. Berdasarkan skor MMAS-8 pada kelompok kontrol sebelum dan setelah pemberian booklet yaitu 3,4 menjadi 2,35 sedangkan kelompok intervensi yaitu 4,45 menjadi 0,8. Hasil uji korelasi Spearman menunjukkan bahwa terdapat hubungan yang kuat $(r=0,783)$ antara kadar glukosa darah sewaktu dengan skor MMAS8 pada pasien DM tipe 2 dalam menggambarkan tingkat kepatuhan pasien dengan taraf kepercayaan $p=0,000(\mathrm{p}<0,05)$, dimana nilai p menunjukkan bahwa edukasi DM melalui pemberian booklet efektif membantu meningkatkan kepatuhan pasien yang dapat dilihat dari skor MMAS-8 rendah dan kadar GDS yang rendah.

Kata kunci: DM Tipe 2, MMAS-8, Booklet, Kepatuhan

\section{Pendahuluan}

Diabetes Melitus (DM) adalah penyakit metabolik kronis yang ditandai dengan peningkatan kadar glukosa dalam darah yang menyebabkan kerusakan serius pada jantung, pembuluh darah, mata, ginjal, dan saraf. Tipe yang paling umum adalah diabetes melitus tipe 2, biasanya terjadi pada orang dewasa, dimana tubuh menjadi resisten terhadap insulin atau tidak cukup untuk memproduksi insulin [1]. Sejak tahun 1980, prevalensi global DM meningkat hampir dua kali lipat dari 4,7\% menjadi $8,5 \%$ pada populasi orang dewasa. China menduduki posisi pertama dengan prevalensi sebanyak 114,4 juta jiwa, diikuti India dan Amerika Serikat masingmasing sebanyak 72,9 dan 30,2 juta jiwa. Indonesia menduduki urutan ke-6 dengan jumlah 10,3 juta jiwa [2]. Berdasarkan hasil riset Badan Pusat Statistik Provinsi Sulawesi Tenggara tahun 2016, DM menempati urutan ke-5 jumlah kasus 10 penyakit terbanyak di Sulawesi Tenggara yaitu sebanyak 3.206 jiwa. WHO memprediksi kenaikan jumlah penderita diabetes melitus di Indonesia dari 8,4 juta pada tahun 2000 menjadi sekitar 21,3 juta pada tahun 2030 [3].

Ketidakpatuhan terhadap terapi diabetes melitus merupakan faktor kunci yang menghalangi pengontrolan kadar gula darah sehingga berpengaruh terhadap hasil terapi. Penyebab ketidakpatuhan sangat kompleks termasuk kompleksitas regimen obat, perilaku, biaya obat, usia, rendahnya dukungan sosial, dan problem kognitif [4]. Ketidakpatuhan terhadap pengobatan penderita diabetes melitus dapat dikaitkan dengan peningkatan jumlah pasien rawat inap dan meningkatnya angka mortalitas. Perkiraan yang ada menyatakan bahwa $20 \%$ dari jumlah pasien rawat inap dirumah sakit adalah merupakan akibat dari ketidakpatuhan pasien terhadap pengobatan [5].

Salah satu cara untuk meningkatkan kepatuhan pasien yaitu dengan pemberian edukasi tentang diabetes, sehingga membuat pasien paham dengan penyakitnya dan merubah perilaku seperti manajemen diri selama pengobatannya. Hal tersebut dapat mengurangi biaya perawatan kesehatan karena meminimalkan terjadinya komplikasi Dalam melakukan edukasi ini maka dapat menggunakan alat bantu atau media, baik media audio, visual dan audio visual. Salah satu contoh media visual adalah booklet [6]. Booklet adalah suatu media untuk menyampaikan pesan-pesan kesehatan dalam bentuk buku, baik berupa tulisan maupun gambar [7]. Booklet merupakan media massa cetak yang bertujuan untuk menyebarkan informasi dalam bentuk tulisan dan gambar. Booklet memiliki beberapa kelebihan yaitu dapat dipelajari setiap saat karena berbentuk buku. Selain itu booklet dapat memuat banyak informasi. Adanya booklet yang menjadi pegangan juga berpengaruh terhadap pengetahuan responden sehingga edukasi tidak hanya berlangsung pada saat bertatap muka tetapi dapat dilakukan mandiri oleh responden[8]. Puspitasari [9] menyatakan bahwa pemberian booklet efektif membantu meningkatkan kepatuhan pengobatan pasien DM tipe 2 di Puskesmas Bakti Jaya Kota Depok ditinjau dari penurunan skor MMAS-8 dan kadar HbA1c. Berdasarkan permasalahan di atas, maka perlu dilakukan penelitian ini untuk melihat efektivitas penggunaan booklet terhadap tingkat kepatuhan minum obat pasien DM tipe 2 di puskesmas Wua-Wua Kota Kendari.

\section{Metode}

\subsection{Populasi dan Sampel}

Populasi penelitian ini yaitu seluruh pasien penderita diabetes melitus tipe 2 yang datang berobat di Puskesmas Wua-Wua Kota Kendari periode Januari-Desember tahun 2017 adalah sebanyak 73 pasien. Sampel yang digunakan adalah sebanyak 40 pasien yang dibagi menjadi 2 kelompok yaitu kelompok kontrol dan kelompok intervensi masingmasing sebanyak 20 pasien. Kriteria inklusi adalah pasien DM tipe 2 yang menggunakan obat antidiabetes 
oral tunggal maupun kombinasi dalam waktu minimal 2 bulan/lebih, dengan atau tanpa penyakit penyerta, berumur $\geqslant 45$ tahun dan dapat membaca dan menulis. Kriteria ekslusi yaitu pasien wanita hamil, pasien yang menggunakan insulin dan pasien yang melakukan pengobatan herbal atau alternatif lain.

\subsection{Jenis Penelitian}

Penelitian ini merupakan jenis penelitian kuasi eksperimen (Quasi Experiment) dengan jenis rancangan non-equivalent control group design. Peneliti melakukan pretest pada kedua kelompok penelitian dan diikuti intervensi pada kelompok eksperimen. Setelah beberapa waktu kemudian dilakukan post test pada kedua kelompok tersebut [10]. Intervensi yang diberikan berupa pemberian booklet penggunaan obat untuk pasien DM Tipe 2 . Pada tahap awal dan akhir penelitian, subjek penelitian diberikan kuesioner yang didesain untuk mengukur tingkat kepatuhan pasien, yaitu kuesioner MMAS-8 dan diukur kadar glukosa darah sewaktu menggunakan alat glukosa darah sewaktu yaitu Nesco Auto Check.

Subjek yang digunakan dalam penelitian ini adalah pasien DM yang bersedia menjadi responden dan mengisi formulir kesediaan yang telah disediakan. Selanjutnya, responden diberikan pretest dengan mengisi kuesioner MMAS-8 dan diukur kadar glukosa darah sewaktu untuk menilai kepatuhan dalam menggunakan obat antidiabetes oral. Setelah itu responden diberikan booklet pengobatan DM. Setelah 4 minggu, responden diberikan posttest dengan mengisi kuesioner MMAS-8 dan diukur kembali glukosa darah sewaktunya untuk menilai perubahan kepatuhan antara sebelum dan setelah pemberian booklet.

\subsection{Analisis Data}

Analisis data menggunakan aplikasi SPSS (Statistical Product and Service Solutions) secara univariat dan bivariat. Analisis univariat menggunakan uji deskriptif, uji shapiro-wilk, uji McNemar, uji wilcoxon dan uji mann-whitney. Analisis bivariat menggunakan uji korelasi spearman.

\section{Hasil dan Pembahasan}

Data karakteristik pasien DM Tipe 2 di Puskesmas Wua-WuaKota Kendari Tahun 2018 dapat dilihat pada tabel 1 .

Tabel 1 menunjukkan bahwa pasien DM tipe 2 di Puskesmas Wua-Wua Kota Kendari Tahun 2018 sebanyak $60 \%$ (24 pasien) berjenis kelamin perempuan dan 40\% (16 pasien) berjenis kelamin lakilaki. Menurut Amerycan Diabetes Association [11] perbedaan jenis kelamin dapat mempengaruhi prevalensi dan outcome diabetes. DM tipe 2 berkembang lebih sering pada wanita dengan diabetes melitus gestasional. Kejadian DM tipe 2 pada wanita dikaitkan dengan menarche dini, siklus yang tidak teratur, atau polycystic ovary syndrome (PCOS) yang terbukti berisiko lebih tinggi. Selain itu, faktor risiko DM tipe 2 yang paling penting pada wanita dikaitkan dengan komplikasi akut dan jangka panjang pada ibu dan keturunan [12].

Tabel 1. Data Karakteristik Pasien DM Tipe 2 di Puskesmas Wua-Wua Kota Kendari Tahun 2018

\begin{tabular}{llcc}
\hline No & Karakteristik & $\begin{array}{c}\text { Frekuensi } \\
(\mathbf{n = 4 0})\end{array}$ & $\begin{array}{c}\text { Persentase } \\
(\boldsymbol{\%})\end{array}$ \\
\hline 1. & Jenis Kelamin & & \\
& Laki-laki & 16 & 40 \\
& Perempuan & 24 & 60 \\
2. & Umur & & \\
& 45-59 tahun & 29 & 72,5 \\
& Z60 tahun & 11 & 27,5 \\
3. & Tingkat & & \\
& Pendidikan & & \\
& Dasar & 13 & 32,5 \\
& Menengah & 20 & 50 \\
& Tinggi & 7 & 17,5 \\
4. Pekerjaan & & 27,5 \\
& Bekerja & 11 & 72,5 \\
\hline & Tidak Bekerja & 29 & \\
\hline
\end{tabular}

(Sumber data : Data Primer, 2018)

Dilihat dari segi umur, sebanyak 72,5\% (29 pasien) memiliki rentang usia berkisar antara 45-59 tahun dan $27,5 \%$ (11 pasien) berusia lebih dari atau sama dengan 60 tahun. Penelitian lain menyebutkan bahwa pada kelompok umur 41-64 tahun memiliki risiko untuk menderita diabetes melitus 3,3 kali lebih mudah dibanding dengan kelompok umur 25-40 tahun [13]. Faktor resiko DM umumnya meningkat di usia lebih dari 40 tahun, hal ini disebabkan pada kisaran usia tersebut metabolisme tubuh mulai menurun [3].

Dari segi tingkat pendidikan, sebanyak 32,5\% (13 pasien) memiliki tingkat pendidikan dasar, 50\% (20 pasien) memiliki tingkat pendidikan menengah dan sebanyak $17,5 \%$ (7 pasien) memiliki tingkat pendidikan tinggi. Menurut Joseph [15] bahwa beberapa studi prospektif menemukan bahwa pendidikan rendah berhubungan dengan kejadian diabetes tipe 2. Orang-orang yang memiliki tingkat pendidikan yang rendah, pengetahuanya mengenai kesehatan tentu tidak terlalu mendalam. Hal ini bisa 
menjadi penyebab mereka tidak mengetahui penyakit DM secara lebih mendalam [16]. Menurut Irawan [17] orang dengan pendidikan tinggi biasanya akan memiliki banyak pengetahuan tentang kesehatan, mempunyai kesadaran dalam menjaga kesehatan dan mempengaruhi aktivitas fisik yang akan dilakukan.

Sedangkan dari segi pekerjaan, sebanyak $27,5 \%$ (11 pasien) masih bekerja dan 72,5\% (29 pasien) tidak bekerja. Berdasarkan penelitian, diketahui bahwa aktivitas fisik menjadi faktor risiko yang kuat untuk penyakit DM tipe 2. Aktivitas fisik sedang dan kuat dikaitkan dengan risiko diabetes tipe 2 yang lebih rendah. Bukti dari aktivitas fisik sebagai contoh intervensi gaya hidup yang sukses menunjukkan hasil bahwa onset diabetes tipe 2 dapat dicegah atau ditunda. Aktivitas fisik memainkan peran penting dalam menunda atau pencegahan perkembangan penyakit diabetes tipe 2 pada mereka yang berisiko baik secara langsung dengan meningkatkan sensitivitas insulin dan secara tidak langsung mengurangi resistensi insulin serta perubahan pada massa dan komposisi tubuh [15].

Data karakteristik penyakit dan penggunaan obat Pasien DM Tipe 2 Puskesmas Lepo-Lepo Kota Kendari Tahun 2018 disajikan dalam tabel 2. Dari tabel tersebut dapat dilihat bahwa sebanyak $42,5 \%$ pasien DM tipe 2 di Puskesmas Wua-Wua kota Kendari Tahun 2018 disertai dengan penyakit penyerta. Penyakit penyerta merupakan penyakit yang muncul bersamaan dengan pasien yang menderita DM Tipe 2. Penyakit penyerta yang diderita responden paling banyak yaitu hipertensi sebanyak 12 pasien (30\%), kolesterol 3 pasien (7,5\%) serta hipertensi dan kolesterol sebanyak 2 pasien (5\%). Resistensi insulin berperan pada patogenesis hipertensi, insulin merangsang saraf simpatis, meningkatkan reabsorbsi natrium ginjal, mempengaruhi transport kation dan mengakibatkan hipertrofi sel otot polos pembuluh darah yang menyebabkan naiknya tekanan darah. Beberapa literatur mengaitkan hipertensi dengan resistensi insulin sebagai penyebab timbulnya DM tipe 2. Selain itu, teori lainnya juga menyatakan bahwa pengaruh hipertensi terhadap kejadian DM disebabkan oleh penebalan pembuluh darah arteri yang menyebabkan diameter pembuluh darah menjadi menyempit. Hal tersebut akan menyebabkan proses pengangkutan glukosa dari dalam darah menjadi terganggu sehingga dapat terjadi hiperglikemia dan berakhir DM tipe 2 [18].

Berdasarkan hasil penelitian, pasien yang diresepkan obat tunggal paling banyak adalah metformin yaitu sebanyak 14 pasien (35\%), glimepirid sebanyak 3 pasien $(7,5 \%)$ dan glibenklamid 1 pasien
$(2,5 \%)$. Sementara itu, pasien yang mendapatkan obat kombinasi metformin dan glimepirid sebanyak 19 pasien $(47,5 \%)$ dan kombinasi metformin dan glibenklamid sebanyak 3 pasien $(7,5 \%)$. Berdasarkan hasil penelitian yang dilakukan, obat ADO tunggal yang paling banyak diresepkan adalah Metformin. Terapi DM tipe 2 dimulai dengan monoterapi (pemberian obat tunggal) yaitu metformin disertai dengan pengelolaan gaya hidup. Metformin dipilih karena memiliki khasiat tinggi, resiko hipoglikemik yang rendah serta harganya yang murah [19]. Menurut Sari dkk. [20] penggunaan golongan obat anti hiperglikemik oral berdasarkan mekanisme kerjanya yaitu golongan penghambat glukoneogenesis sebanyak 54,1\%. Golongan penghambat glukoneogenesis tersebut yang paling banyak digunakan adalah jenis obat metformin.

Tabel 2. Karakteristik Penyakit dan Penggunaan Obat Pasien DM Tipe 2

\begin{tabular}{|c|c|c|c|}
\hline No & Karakteristik & $\begin{array}{c}\text { Frekuensi } \\
(n=40)\end{array}$ & $\begin{array}{c}\text { Persen } \\
(\%)\end{array}$ \\
\hline \multirow[t]{6}{*}{1.} & Penyakit Penyerta & & \\
\hline & Tanpa Penyakit & 23 & 57,5 \\
\hline & Penyerta & & \\
\hline & DM + Hipertensi & 12 & 30 \\
\hline & DM + Kolesterol & 3 & 7,5 \\
\hline & $\begin{array}{l}\text { DM + Hipertensi + } \\
\text { Kolesterol }\end{array}$ & 2 & 5 \\
\hline \multirow[t]{7}{*}{2.} & Jumlah obat & & \\
\hline & $\begin{array}{l}\text { Antidiabetik Oral } \\
\text { yang diberikan }\end{array}$ & & \\
\hline & Metformin & 14 & 35 \\
\hline & Glimepirid & 3 & 7,5 \\
\hline & Glibenklamid & 1 & 2,5 \\
\hline & $\begin{array}{l}\text { Metformin + } \\
\text { Glimepirid }\end{array}$ & 19 & 47,5 \\
\hline & $\begin{array}{l}\text { Metformin + } \\
\text { Glibenklamid }\end{array}$ & 3 & 7,5 \\
\hline \multirow[t]{7}{*}{3.} & $\begin{array}{l}\text { Mendapatkan } \\
\text { Obat Lain }\end{array}$ & & \\
\hline & Amlodipin & 20 & 50 \\
\hline & Simvastatin & 6 & 15 \\
\hline & Captopril & 3 & 7,5 \\
\hline & Valsartan & 3 & 7,5 \\
\hline & $\begin{array}{l}\text { Amlodipin dan } \\
\text { simvastatin }\end{array}$ & 5 & 12,5 \\
\hline & $\begin{array}{l}\text { Candesartan+Spiro } \\
\text { nolakton }\end{array}$ & 3 & 7,5 \\
\hline \multicolumn{4}{|c|}{$\overline{\text { (Sumber data : Data Primer, 2018) }}$} \\
\hline \multicolumn{4}{|c|}{$\begin{array}{l}\text { Berdasarkan karakteristik penggunaan obat la } \\
\text { hasil penelitian menunjukkan bahwa pasien deng } \\
\text { penyakit penyerta hipertensi kebanyakan mendap } \\
\text { terapi amlodipin. Menurut Yulianti dkk. [21] lebih da } \\
50 \% \text { penderita DM tipe } 2 \text { vang mengalami hiperten }\end{array}$} \\
\hline
\end{tabular}


dominan mendapatkan terapi amlodipin (24\%) untuk pengobatan hipertensi. Amlodipin merupakan obat antihipertensi golongan antagonis kalsium yang pengunaannya sebagai monoterapi atau dikombinasikan dengan golongan obat lain seperti diuretik, ACE-inhibitor, ARB II atau beta bloker dalam penatalaksanaan hipertensi. Amlodipin juga merupakan salah satu obat antihipertensi tahap pertama sejak JNC IV dan WHO-ISH 1989 selain diuretik yang merupakan rekomendasi JNC VII sebagai obat antihipertensi tahap pertama.

\section{Tingkat Kepatuhan Pasien DM Tipe 2 Berdasarkan Kadar GDS}

Tingkat kepatuhan merupakan penilaian terhadap pasien yang digunakan untuk mengetahui apakah seorang pasien telah mengikuti aturan penggunaan obat dalam menjalani terapi [3]. Penelitian ini menggunakan pengukuran gula darah sewaktu untuk menilai tingkat kepatuhan pasien DM tipe 2 dalam menggunakan obat antidiabetik oral (ADO). Kadar glukosa darah sewaktu penderita DM tipe 2 dikatakan terkontrol yaitu jika kadarnya $\leq$ $200 \mathrm{mg} / \mathrm{dL}$ dan tidak terkontrol yaitu $\geq 200 \mathrm{mg} / \mathrm{dL}$ [22]. Penelitian ini menggunakan pengukuran glukosa darah sewaktu untuk menilai kepatuhan pengobatan pasien DM tipe 2. Hasil pengukuran kadar GDS pasien pada kelompok kontrol dan kelompok intervensi dapat dilihat pada gambar 1 .

Berdasarkan gambar grafik diatas dapat dilihat bahwa nilai rata-rata kadar GDS pada kelompok kontrol awalnya 296,2 mg/dL turun menjadi 265,85 $\mathrm{mg} / \mathrm{dL}$ sedangkan pada kelompok intervensi nilai ratarata GDS awalnya 275,7 $\mathrm{mg} / \mathrm{dL}$ turun menjadi 198,1 $\mathrm{mg} / \mathrm{dL}$. Hal ini menunjukkan bahwa kadar GDS kelompok kontrol dan kelompok intervensi sebelum pemberian booklet di atas normal $(200 \mathrm{mg} / \mathrm{dL}$. Setelah pemberian booklet kadar GDS kelompok kontrol di atas nomal sedangkan kelompok intervensi normal. Selisih penurunan nilai rata-rata kadar GDS pada kelompok kontrol yaitu 34,4 sedangkan pada kelompok intervensi selisih penurunan nilai rata-rata kadar GDS lebih besar yaitu 77,6. Selisih penurunan nilai rata-rata kadar GDS yang lebih besar pada kelompok intervensi dibanding kelompok kontrol disebabkan kurangnya pengetahuan kelompok kontrol tentang pengobatan dan penyakit DM sehingga mempengaruhi tingkat kepatuhannya dalam minum obat. World Health Organization (2016) menyatakan bahwa manfaat yang lebih besar di bidang kesehatan dunia akan diperoleh dengan peningkatan kepatuhan terapi dari pada pengembangan obat baru. Intervensi yang dapat menstimulasi timbulnya kepatuhan terapi yang lebih baik, walaupun kecil akan bermanfaat besar dalam peningkatan kesehatan publik.

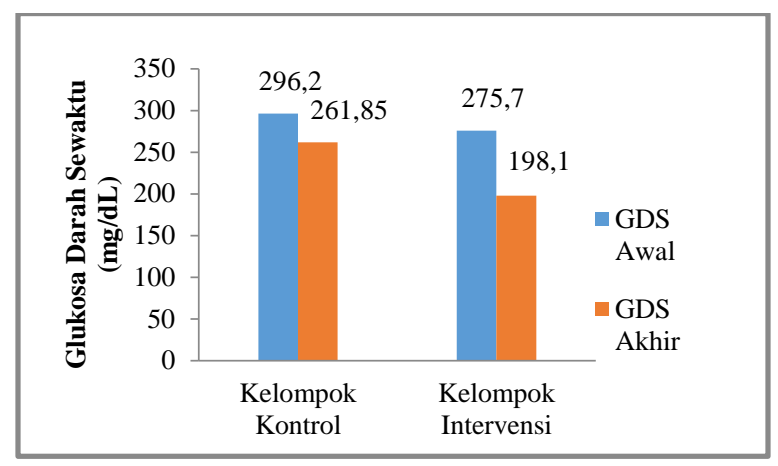

Gambar 1. Grafik Kadar Glukosa Darah Sewaktu Pasien pada Kelompok Kontrol dan Kelompok Intervensi

Selanjutnya dilakukan uji statistik untuk melihat signifikansi penurunan kadar GDS sebelum dan setelah pemberian booklet dan diperoleh hasil pada kelompok kontrol dengan nilai signifikan $p=0,125$ $(p>0,05)$ dan kelompok intervensi $p=0,000(\mathrm{p}<0,05)$. Hasil ini menunjukkan bahwa pada kelompok kontrol tidak terdapat perbedaan bermakna pasien yang mengalami penurunan kadar GDS sebelum dan setelah pemberian booklet. Sedangkan pada kelompok intervensi terdapat perbedaan bermakna pasien yang mengalami penurunan kadar GDS sebelum dan setelah pemberian booklet. Penelitian lain yang dilakukan oleh Sutanto yang menggunakan media booklet sebagai instrumen edukasi guide bagi penderita asma tentang cara penggunaan inhaler menunjukkan terdapat perbedaan pengetahuan yang signifikan antara kelompok uji dan kontrol $(\mathrm{p}=0,000)$. Selain itu penelitian yang dilakukan oleh Kristina yang juga menggunakan media booklet sebagai instrumen edukasi penggunaan antibiotik yang tepat bagi pasien yang membawa resep antibiotik ke apotik umum menunjukkan adanya perbedaan tingkat pengetahuan antara kelompok uji dan kelompok kontrol dengan nilai signifikansi $(\mathrm{p}=0,02)[3]$.

\section{Tingkat Kepatuhan Pasien DM Tipe 2 Berdasarkan Skor MMAS-8}

MMAS-8 memiliki sensitivitas $93 \%$ yang mengindikasikan bahwa skala tersebut cukup baik digunakan untuk menilai kepatuhan minum obat pasien [23]. Pengukuran tingkat kepatuhan pasien dilakukan diawal dan setelah 4 minggu perlakuan. Skor penilaian MMAS-8 dibagi menjadi 3 kategori, yaitu kepatuhan rendah dengan skor lebih dari 2, kepatuhan sedang dengan skor 1-2, dan kepatuhan tinggi dengan skor 0 . Hasil pengukuran skor MMAS- 
8 pasien pada kelompok kontrol dan kelompok intervensi dapat dilihat pada gambar 2 .

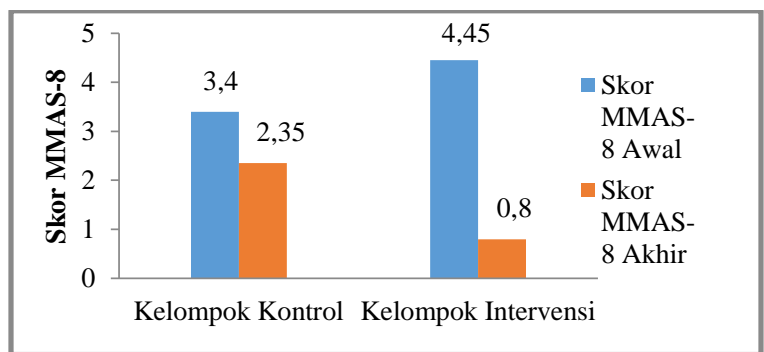

Gambar 2. Grafik Skor MMAS-8 Pasien pada Kelompok Kontrol dan Kelompok Intervensi

Berdasarkan gambar grafik diatas dapat dilihat bahwa nilai rata-rata skor MMAS-8 pada kelompok kontrol awalnya 3,4 (kepatuhan rendah) turun menjadi 2,35 (tingkat kepatuhan sedang) sedangkan pada kelompok intervensi nilai rata-rata skor MMAS-8 awalnya yaitu 4,45 (tingkat kepatuhan rendah) turun menjadi 0,8 (tingkat kepatuhan tinggi). Dari hasil ini diperoleh selisih penurunan nilai rata-rata skor MMAS pada kelompok kontrol yaitu 1,05 sedangkan pada kelompok intervensi selisih penurunan nilai rata-rata skor lebih besar yaitu 3,95. Selisih penurunan nilai rata-rata skor MMAS-8 yang lebih kecil pada kelompok kontrol disebabkan karena kurangnya pengetahuan pasien tentang pengobatan dan penyakit DM sehingga mereka cenderung tidak patuh dalam pengobatan. Dari penurunan rata-rata skor MMAS-8 dapat disimpulkan bahwa pemberian booklet dapat meningkatkan kepatuhan minum obat pasien DM tipe 2 di Puskesmas Wua-Wua Kota Kendari.

Selanjutnya dilakukan uji statistik Wilcoxon untuk melihat adanya perbedaan nilai signifikan antara tingkat kepatuhan pasien sebelum dan setelah pemberian booklet pada kelompok kontrol dan kelompok intervensi. Pada kelompok kontrol diperoleh nilai signifikansi $p=0,066(p>0,05)$ yang artinya tidak terdapat perbedaan bermakna tingkat kepatuhan pasien sebelum dan setelah pemberian booklet. Sedangkan pada kelompok intervensi terdapat perbedaan bermakna kepatuhan pasien sebelum dan setelah pemberian booklet dengan nilai signifikansi $p=0,000$ ( $p<0,05)$. Berdasarkan hasil ini, dapat dikatakan bahwa pemberian booklet dapat meningkatkan kepatuhan minum obat pasien DM tipe 2. Perbedaan tingkat kepatuhan antara kelompok uji dan kontrol pada penelitian ini menyokong hasil penelitian yang dilakukan oleh Kristina yang membandingkan tingkat kepatuhan antara pasien yang diberi edukasi dengan metode booklet tentang penggunaan antibiotik yang tepat dengan pasien yang hanya diberikan informasi oral saja. Hasil penelitian yang dilakukan oleh Kristina menunjukkan adanya perbedaan tingkat kepatuhan yang signifikan antara pasien yang diberi booklet antibiotik dengan yang tidak dengan nilai signifikansi $(\mathrm{p}=0,011)$ [3].

Perbandingan Tingkat Kepatuhan Pasien DM Tipe 2 antara Kelompok Kontrol dan Kelompok Intervensi Berdasarkan Kadar GDS dan Skor MMAS-8

Penelitian ini, selain untuk melihat perbedaan hasil sebelum dan setelah perlakuan pada masingmasing kelompok, juga dilakukan pengujian untuk melihat ada tidaknya perbedaan hasil antara dua kelompok perlakuan dengan menggunakan uji MannWhitney. Uji ini dilakukan karena jenis data yang digunakan tidak terdistribusi normal walaupun telah ditransformasi. Hasil analisis selisih kadar GDS menunjukkan bahwa terdapat perbedaan bermakna antara kelompok kontrol dan kelompok intervensi dengan nilai signifikan $\mathrm{p}=0,005(p<0,05)$. Nilai ratarata selisih kadar GDS pada kelompok intervensi lebih besar yaitu 75,50 dibandingkan dengan kelompok kontrol yaitu 34,35. Jadi, dapat dikatakan bahwa kelompok intervensi yang memperoleh booklet memiliki penurunan kadar gula darah sewaktu yang lebih baik dibandingkan kelompok kontrol.

Hasil analisis selisih skor MMAS-8 menunjukkan bahwa terdapat perbedaan bermakna antara kelompok kontrol dan kelompok intervensi dengan nilai signifikan $p=0,001(p<0,05)$. Nilai selisih rata-rata skor MMAS-8 pada kelompok intervensi lebih besar yaitu 3,65 dibandingkan dengan kelompok kontrol yaitu 1,05. Jadi, dapat dikatakan bahwa kelompok intervensi yang memperoleh booklet memiliki kepatuhan minum obat yang lebih baik dibandingkan kelompok kontrol.

\section{Hubungan antara Kadar Glukosa Darah Sewaktu terhadap Tingkat Kepatuhan}

Uji korelasi digunakan untuk mengetahui keeratan hubungan antara dua variabel dan untuk mengetahui arah hubungan yang terjadi. Uji korelasi pada penelitian ini digunakan untuk mengetahui hubungan antara glukosa darah sewaktu dengan skor MMAS-8 menggunakan uji Spearman. Uji korelasi Spearman adalah uji statistik yang ditujukan untuk mengetahui hubungan antara dua atau lebih variabel berskala ordinal [24]. Hasil uji korelasi antara GDS dengan skor MMAS-8 dapat dilihat pada tabel 3 .

Tabel 3. Hasil Uji Korelasi Spearman pada Kelompok Intervensi

\begin{tabular}{ccc}
\hline & $\begin{array}{c}\text { Selisih gula } \\
\text { darah } \\
\text { intervensi }\end{array}$ & $\begin{array}{c}\text { Selisih } \\
\text { kepatuhan } \\
\text { intervensi }\end{array}$ \\
\hline $\mathrm{R}$ & 1,000 &, $783 * *$
\end{tabular}




\begin{tabular}{|c|c|c|c|}
\hline Selisih gula & $P$ & - & ,000 \\
\hline $\begin{array}{l}\text { darah } \\
\text { intervensi }\end{array}$ & $\mathrm{N}$ & 20 & 20 \\
\hline
\end{tabular}

Berdasarkan hasil uji korelasi Spearman antara variabel gula darah sewaktu dan kepatuhan pasien yang diperoleh hasil signifikan $p=0,000 \quad(p<0,01)$ menunjukkan bahwa terdapat korelasi yang bermakna antara dua variabel yang diuji dengan taraf kepercayaannya sebesar 99\%. Nilai koefisien korelasi Spearman pada kelompok intervensi didapatkan sebesar 0,783, nilai ini menandakan hubungan yang kuat antara variabel GDS dan Skor MMAS-8. Dari tingkat korelasi yang kuat ini menjelaskan bahwa terdapat hubungan antara GDS dangan skor MMAS-8 terhadap tingkat kepatuhan pasien. Dengan demikian, dapat dikatakan bahwa pasien DM tipe 2 yang memiliki tingkat kepatuhan tinggi dapat digambarkan dengan skor MMAS-8 yang rendah dan kadar GDS yang juga rendah. Hal ini sejalan dengan penelitian Sabarudin [8] bahwa terdapat hubungan yang signifikan antara skor MMAS-8 pada pasien DM tipe 2 dengan kadar GDS Pada pasien DM tipe 2 di Puskesmas Lepo-lepo Kota Kendari dengan angka koefesien korelasi Spearman sebesar 575** artinya besar korelasi antara variabel GDS dan skor MMAS-8 adalah sebesar 0,575 atau cukup kuat dengan tanda dua bintang $(* *)$ menunjukkan korelasi signifikan pada angka signifikansi sebesar 0,01. Signifikansi memberikan gambaran mengenai bagaimana suatu hasil mempunyai kesempatan untuk benar. Jika nilai signifikansi sebesar 0,01, maka taraf kepercayaannya sebesar $99 \%$ dan untuk salah sebesar 1\%. Jika tidak ada tanda $(* *)$ dua bintang, maka secara otomatis signifikansinya sebesar 0,05. Puspitasari [25] menyatakan bahwa terdapat korelasi positif $(\mathrm{r}=0,5512)$ antara kadar HbA1C dengan skor MMAS pada pasien. Pemberian booklet efektif membantu meningkatkan kepatuhan minum obat pasien DM tipe 2 di Puskesmas Bakti Jaya Kota Depok.

\section{Kesimpulan}

Berdasarkan penelitian yang dilakukan pada pasien DM tipe 2 di Puskesmas Wua-Wua Kota Kendari, diperoleh kesimpulan sebagai berikut:

1. Terdapat perbedaan tingkat kepatuhan minum obat pasien DM tipe 2 di Puskesmas Wua-Wua Kota Kendari sebelum dan setelah pemberian booklet. Berdasarkan kadar GDS pada kelompok kontrol sebelum dan setelah pemberian booklet yaitu 296,2 mg/dL menjadi 261,85 sedangkan kelompok intervensi yaitu $275,7 \mathrm{mg} / \mathrm{dL}$ menjadi 198,1 mg/dL. Berdasarkan nilai skor MMAS-8 pada kelompok kontrol sebelum dan setelah pemberian booklet yaitu 3,4 menjadi 2,35, sedangkan kelompok intervensi yaitu 4,45 menjadi 0,8 .

2. Terdapat hubungan yang kuat antara kadar GDS dengan skor MMAS-8 pada pasien DM tipe 2 dalam menggambarkan tingkat kepatuhan pasien dengan taraf kepercayaan $p<0,01$.

\section{Ucapan Terima Kasih}

Ucapan terima kasih kepada Fakultas Farmasi Universitas Halu Oleo atas dukungan dan bantuan dalam pelaksanaan penelitian ini.

\section{Daftar Pustaka}

1. Cho N, Shaw JE, Karuranga S, Huang Y, da Rocha Fernandes JD, Ohlrogge AW, et al. IDF Diabetes Atlas: Global estimates of diabetes prevalence for 2017 and projections for 2045. Diabetes Res Clin Pract. 2018;138:271-81.

2. Carracher AM, Marathe PH, Close KL. International Diabetes Federation 2017. J Diabetes. 2018;10(5):353-6.

3. Rasdianah N, Martodiharjo S, Andayani TM, Hakim L. Gambaran kepatuhan pengobatan pasien diabetes melitus tipe 2 di Puskesmas Daerah Istimewa Yogyakarta. Indones J Clin Pharm. 2016;5(4):249-57.

4. Alfian R. Korelasi Antara Kepatuhan Minum Obat dengan Kadar Gula Darah pada Pasien Diabetes Melitus Rawat Jalan di RSUD Dr. H. Moch. Ansari Saleh Banjarmasin. J Pharmascience. 2019;2(2):15-23.

5. Broadbent E, Donkin L, Stroh JC. Illness and treatment perceptions are associated with adherence to medications, diet, and exercise in diabetic patients. Diabetes Care. 2011;34(2):338-40.

6. Sagala RM, Arozal W, Sauriasari R, Keban S. Evaluasi Penerapan Booklet dan Edukasi Apoteker pada Pasien Diabetes Melitus Tipe $2 \mathrm{di}$ Rumah Sakit Mayapada Tangerang. Pharm Sci Res. 2017;4(2):102-10.

7. Zulaekah S. Pendidikan gizi dengan media booklet terhadap pengetahuan gizi. KEMAS J Kesehat Masy. 2012;7(2):127-33.

8. Sabarudin, Kasmawati H, Ode W, Madjid I, Nirmala F. The Effectivity Analysis of Booklet on Adherence Level of Patient with Type 2 Diabetes Mellitus in Lepo-Lepo Public Health Center of Kendari. Int $\mathbf{J}$ Multidisiplinary Curr Educ Res. 2019;1(6):11-6.

9. Puspitasari AW, Andrajati R, Bahtiar A. Analisis Efektivitas Booklet Obat terhadap Tingkat 
Kepatuhan Pasien Diabetes Melitus Tipe 2. J Manaj dan Pelayanan Farm ( JMPF ) J Manag Pharm Pract [Internet]. 2012;2(4):195-202. Available from: http://jmpf.farmasi.ugm.ac.id/index.php/1/articl e/view/94

10. Faizah EN, Fibriana AI. Hubungan Antara Status Medical Check Up Terhadap. Unnes J Public Heal. 2016;5(1):110-9.

11. Herman WH, Petersen M, Kalyani RR. Response to Comment on American Diabetes Association. Standards of Medical Care in Diabetes - 2017. Diabetes Care 2017; 40 (Suppl. 1): S1-S135. Diabetes Care. 2017;40(7):e94-5.

12. Kautzky-Willer A, Baggio G, Rossi MC, Lapolla A, Russo GT. Type 2 diabetes and cardiovascular risk in women 2016. Int $\mathrm{J}$ Endocrinol. 2017;2017.

13. Rahajeng E. Pengaruh Konsumsi Kopi Terhadap Kejadian Diabetes Melitus Tipe 2 (Studi Follow up Gangguan Toleransi Glukosa di Depok Jawa Barat Tahun 2001-2008). Gizi Indones. 2010;33(2).

14. Adawiyani R. Pengaruh Pemberian Booklet Anemia Terhadap Pengetahuan, Kepatuhan Minum Tablet Tambah Darah Dan Kadar Hemoglobin Ibu Hamil. CALYPTRA. 2013;2(2):1-20.

15. Joseph J, Svartberg J, Njølstad I, Schirmer H. Incidence of and risk factors for type-2 diabetes in a general population: the Troms $\varnothing$ Study. Scand J Public Health. 2010;38(7):768-75.

16. Mongisidi G. Hubungan Antara Status SosioEkonomi dengan Kejadian Diabetes Melitus Tipe 2 Di Poliklinik Interna Blu Rsup Prof. Dr. RD Kandou Manado. J Ilm. 2014;

17. Irawan D. Prevalensi dan Faktor Risiko Kejadian Diabetes Melitus Tipe 2 di Daerah Urban Indonesia (Analisa Data Sekunder Riskesdas 2007). Thesis Universitas Indonesia; 2010.

18. Tedesco MA, Natale F, Di Salvo G, Caputo S, Capasso M, Calabro R. Effects of coexisting hypertension and type II diabetes mellitus on arterial stiffness. J Hum Hypertens. 2004;18(7):469-73.

19. Ariawan MW. Analisis Efektivitas Biaya Pengobatan Pasien Diabetes Tipe 2 dengan Terapi Glibenklamid dan Metformin Pasien BPJS Rawat Inap di RSUD Sukoharjo Tahun 2017. Universitas Setia Budi Surakarta; 2018.

20. Firni Dwi Sari, Inayah, Hamidy MY. Pola Penggunaan Obat Anti Hiperglikemik Oral Pada Pasien Diabetes Melitus Tipe 2 Rawat Inap Di Rumah Sakit X Pekanbaru Tahun 2014. J Online Mhs Bid Kedokt. 2016;3(1):1-14.

21. Yulianti SR, Mukaddas A, Faustine I. Profil pengobatan pasien diabetes mellitus tipe 2 di instalasi rawat inap RSUD Undata Palu tahun 2012. Online J Nat Sci. 2014;3(1):40-6.

22. Siregar D, Sitanggang YF, Paula V. Edukasi Kesehatan Dan Deteksi Dini Hipertensi, Kolesterol, Asam Urat Dan Diabetes Melitus Di Gereja HKBP PPGS. Pros Konf Nas Pengabdi Kpd Masy dan Corp Soc Responsib. 2019;2:437-43.

23. Rosyida L. Kepatuhan Pasien Pada Penggunaan Obat Antidiabetes dengan Metode Pill Count Dan Mmas-8 di Puskesmas Kedurus Surabaya Selatan. UNIVERSITAS AIRLANGGA; 2015.

24. Ambarwati F. Hubungan Tingkat Pendidikan Dan Tingkat Pengetahuan Dengan Kepatuhan Pengguna Pil KB Di Kecamatan Weru Kabupaten Sukoharjo Tahun 2013. Universitas Muhammadiyah Surakarta; 2014.

25. Puspitasari AW. Analisis Efektivitas Pemberian Booklet Obat Terhadap Tingkat Kepatuhan Ditinjau dari Kadar Hemoglobin Terglikasi (HbA1C) dan Morisky Medication Adherence Scale (MMAS)-8 pada Pasien Diabetes Melitus Tipe 2 di Puskesmas Pati Jaya Kota Depok. Univ Indones. 2012; 